\title{
Analisis Campuran Tanah Liat dan Batu Kapur Bukit Pecatu Sebagai Instrumen Pemanen dan Penampung Air Hujan
}

\author{
Ni Wayan Eka Wijayanti" ${ }^{*}$, I Gede Putu Eka Suryana² iD \\ 1,2 Jurusan Teknik Informatika, STMIK STIKOM Indonesia, Denpasar, Bali, Indonesia \\ *Corresponding author: eka.wijayanti2013@gmail.com
}

\begin{abstract}
Penelitian ini berawal dari banyaknya penambangan batu kapur di daerah Bukit Pecatu dan menimbulkan ceruk-ceruk yang dalam. Pada sisi lain, permasalahan kelangkaan air menjadi hal utama, karena karakteristik batuan karst dapat meloloskan, melarutkan, dan meresap air. Kondisi adanya bekas penambangan ceruk serta kesulitan air merupakan dua permasalahan yang berbeda. Namun dalam penelitian ini, mencoba menggabungkan permasalahan tersebut menjadi sebuah solusi dengan tujuan membuat eksperimen yang mampu membuat batu kapur dari Bukit Pecatu memiliki potensi menahan air dalam jangka waktu yang lama dalam bentuk model waduk miniatur. Model waduk miniatur ini dibuat dengan campuran suspensi tanah liat yang berbagai konsentrasi $(0 \%, 5 \%, 10 \%$ dan 15\%). Model waduk miniature ini diuji debit dan daya serap air yang diasumsikan genangan air hujan untuk mengetahui kemampuan dalam menambung air hujan. Hasil dari pengujian tersebut adalah waduk miniature dengan campuran 15\% suspensi tanah liat memiliki kemampuan menahan laju penurunan penyusutan air hujan 0,04L/menit dan memiliki daya serap air yang kecil yaitu 10,91\% dibandingkan dengan konsentrasi yang lainnya. Dengan ini menunjukkan waduk miniatur batu kapur Bukit Pecatu dengan campuran konsentrasi $15 \%$ suspensi tanah liat memiliki potensi sebagai instrumen pemanen dan penampung air hujan. Sehingga hal ini diharapkan dapat di manfaatkan oleh masyarakat desa Bukit Pecatu sebagai salah satu instrumen pemanen dan penampung air hujan.
\end{abstract}

Keywords: Batu Kapur, Tanah Liat, Air hujan, Pemanenan Air Hujan dan Penampungan Air Hujan

\section{Abstract}

This research originated from the large number of limestone mining in the Pecatu Hill area and it caused deep niches. On the other hand, the problem of water scarcity is the main thing, because the characteristics of karst rocks can escape, dissolve and absorb water. The condition of the ex-niche mining and water shortages are two different problems. But in this study, trying to combine these problems into a solution with the aim of making experiments that can make limestone from Pecatu Hill have the potential to hold water for a long time in the form of a miniature reservoir model. This miniature reservoir model is made with a mixture of clay suspensions of various concentrations $(0 \%, 5 \%, 10 \%$ and $15 \%)$. This miniature reservoir model is tested for discharge and absorption of water which is assumed to be rainwater puddle to determine the ability to absorb rainwater. The result of this test is that the miniature reservoir with a mixture of $15 \%$ clay suspension has the ability to withstand a decrease in rainwater shrinkage of $0.04 \mathrm{~L} /$ minute and has a small water absorption capacity of $10.91 \%$ compared to other concentrations. This shows that the miniature limestone reservoir of Pecatu Hill with a mixture of $15 \%$ clay suspension has potential as an instrument for harvesting and collecting rainwater. So this is expected to be utilized by the villagers of Pecatu Hill as an instrument for harvesting and collecting rainwater.

Keywords: Limestone, Clay, Rainwater, Rainwater Harvesting and Rainwater Storage

$\begin{array}{lll}\text { History: } & & \text { Publisher: Undiksha Press } \\ \text { Received } & : \text { 10 July } 2020 & \text { Licensed: This work is licensed under } \\ \text { Revised } & : \text { 18 August } 2020 & \text { a Creative Commons Attribution 3.0 License } \\ \text { Accepted } & : 21 \text { Sepember } 2020 & \text { CC () () } \\ \text { Published } & : 30 \text { October } 2020 & \end{array}$




\section{Introduction}

Desa Adat Pecatu merupakan sebuah wilayah di Kecamatan Kuta Selatan, Badung Bali. Desa ini sangat terkenal sebagai salah satu objek wisata alam dengan morfologi perbukitan batu kapur dengan tebing yang curam. Tiga lokasi di kawasan Bukit Pecatu yang di dominasi oleh batuan kapur adalah bagian barat, tengah dan timur (Ardana \& Aribudiman, 2019). Batu kapur merupakan batuan padat yang mengandung kalsium karbonat $\left(\mathrm{CaCO}_{3}\right)$ (Garinas, 2020), serta merupakan material metastabil karena dalam waktu tertentu dapat berubah menjadi kalsit (Widiarso et al., 2018). Di alam batu kapur memiliki warna putih, putih kekuningan, dan abu-abu hingga hitam. Pemanfaatan batu kapur banyak digunakan dalam berbagai industri, sebagai bahan imbuh dalam industri peleburan logam baik besi maupun bukan besi dan industri kaca (glass); bahan pengisi pada pembuatan barang-barang dari karet, plastik, karton, cat, pasta gigi, dan lain-lain (Megawati et al., 2019). Selain itu, batu kapur juga digunakan sebagai agregat pengeras jalan, pembuatan batu, dan beton (Rochmah, 2016). Banyaknya manfaat dari batu kapur, membuat batu kapur di daerah tersebut banyak di tambang sehingga banyak meninggalkan ceruk-ceruk yang dalam dan dinilai tidak mengindahkan nilai konservatif.

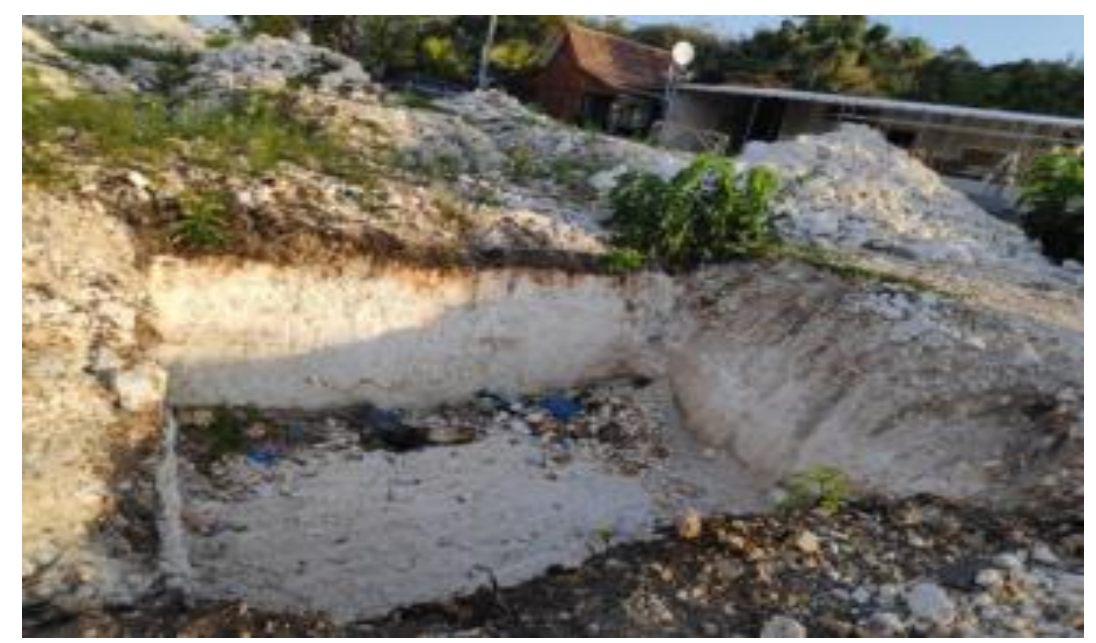

Gambar 1. Hasil Observasi Penambangan Batu Kapur yang Akhirnya Membentuk Ceruk

Permasalahan yang lain adalah kelangkaan air bersih yang di alami oleh warga yang tinggal di daerah perbukitan Pecatu. Sebagian besar lahannya sangat kering dan tandus (Suryana \& Wijayanti, 2020). Dampak kekurangan air sangat dirasakan oleh $100 \mathrm{KK}$ warga desa Pecatu yang tinggal di wilayah perbukitan. Air bersih adalah air yang digunakan untuk keperluan sehari-hari dan akan menjadi air minum setelah dimasak terlebih dahulu yang memenuhi persyaratan bagi sistem penyediaan air minum (VA et al., 2017). Adapun sumber air yang dipergunakan oleh masyarakat untuk keperluan sehari-hari bersumber dari air tanah dan air PDAM (Rohmaningsih et al., 2017). Namun tidak semua masyarakat yang tinggal di daerah perbukitan Desa Pecatu mendapatkan sumber air bersih dari PDAM. Bagi masyarakat yang tinggal di daerah perbukitan sangat mustahil untuk mendapatkan air tanah, karena warga harus melakukan pengeboran tanah dengan ke dalaman \pm 80 meter. Pengeboran tanah untuk sumur ini sangatlah tinggi. Tiap meter pengeboran tanah, memerlukan biaya $\mathrm{Rp}$ 1.000.000, jadi perlu sekitar Rp 80.000.000 untuk mendapat air tanah (Suryana \& Wijayanti, 2020). Besarnya biaya yang dikeluarkan untuk membuat sumur bor ini mengakibatkan warga yang tinggal di perbukitan Pecatu, tidak sanggup melakukan pengeboran tanah, untuk mendapatkan sumber air bersih. Pada sisi lain sistem air tanah umumnya lebih tahan terhadap perubahan iklim daripada sumber air permukaan. Namun perlu diwaspadai, saat penguapan 
meningkat maka badan air tanah kehilangan lebih banyak air. Suhu tinggi juga mempercepat pembentukan kerak tanah sehingga tanah butuh waktu lebih lama agar dapat kembali ke kondisi maksimum untuk meresapkan air hujan. Akibatnya, total volume air yang masuk ke lapisan akuifer (lapisan penahan air) menjadi berkurang (Suprayogi et al., 2017). Sehingga hal ini juga menyebabkan kondisi lahan menjadi tandus dan kering.

Air hujan merupakan sumber air yang tersedia sepanjang tahun dan sangat potensial sebagai sumber air bersih bagi rumah tangga jika ditampung dan disimpan dengan baik. Air hujan ini melimpah sejak lama, tetapi masih saja dibiarkan tanpa pengelolaan, terbuang mengalir ke sungai bahkan tidak diupayakan meresap kembali ke tanah. Pada banyak kasus justru air hujan disalahkan sebagai penyebab terjadinya bencana banjir (Rahim \& Damiri, 2018). Sehingga salah satu cara untuk mengatasi kelangkaan sumber air bersih adalah dengan cara pembuatan tempat pemanen dan penampung air hujan (Mays et al., 2015). Pada musim hujan tentu air hujan sangat melimpah, dan tidak semua air hujan dapat di serap oleh tanah. Air hujan yang tidak terserap akan melimpas begitu saja. Jika air hujan ini ditampung, maka air hujan tersebut dapat dimanfaatkan oleh masyarakat untuk memenuhi kebutuhannya.

Pemanenan hujan merupakan proses memanfaatkan air hujan dengan cara ditampung dan dapat dimanfaatkan untuk berbagai keperluan. Secara garis besar cara pemanenan hujan dapat dibagi kedalam dua cara, yakni dengan mengumpulkan air hujan di atas atap bangunan (roof catchment) dan dilakukan dengan mengumpulkan air hujan di atas permukaan tanah (ground catchment) (Ali et al., 2017). Sistem pemanenan air hujan di atas permukaan tanah (land surface catchment areas) pada dasarnya merupakan metode untuk mengumpulkan air hujan. Jumlah air hujan yang dapat dipanen di atas permukaan tanah dipengaruhi oleh topografi bidang tangkapan serta kemampuan lapisan tanah dalam menahan air (Nurdin et al., 2019). Berdasarkan ruang lingkup implementasinya, teknik pemanenan air hujan dapat di golongkan menjadi dua kategori yaitu: (1) teknik pemanenan air hujan dengan atap bangunan (roof top rain water harvesting), dan (2) teknik pemanenan air hujan (dan aliran permukaan) dengan bangunan reservoir, seperti dalam parit, embung, kolam, waduk, bedungan dan sebagainya (Ali et al., 2017).
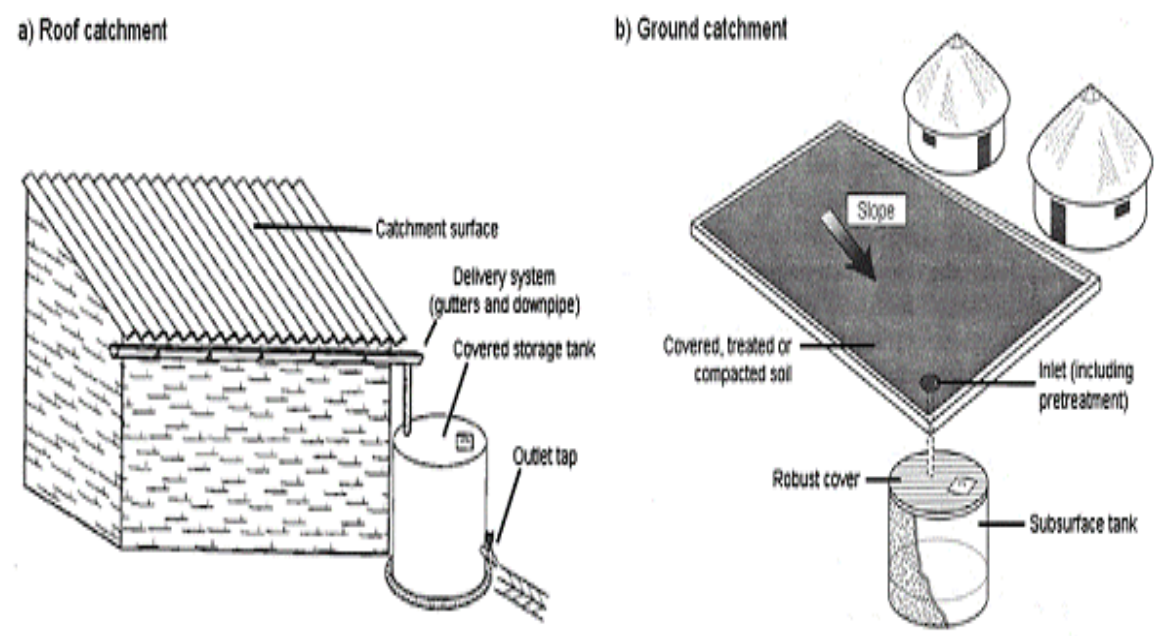

Gambar 2. Model Pemanen Air Hujan 
Penelitian yang dilakukan oleh Riyanto \& Agung Setiawan (2020), yaitu pemanenan air hujan menggunakan Ground Water Tank untuk pemenuhan air baku di lokasi bangunan perkuliahan (lokasi penelitian : kampus 3, UM Purworejo). Hasil penelitian menunjukan potensi volume suplai air hujan didapatkan sebesar $976,99 \mathrm{~m}^{3} /$ tahun, dan penghematan air sebesar 0,76 \% dari total kebutuhan air gedung perkuliahan sebesar $86.400 \mathrm{~m}^{3} /$ tahun. Perhitungan RAB tangki didapatkan sebesar Rp. 93.998.000,00 untuk dimensi tangki tampungan air hujan sebesar 8 × 5 x $3 \mathrm{~m}$. Suprayogi et al (2017) melaporkan pemanfaatan pemanenan air hujan skala individu untuk kebutuhan air bersih pada pulau kecil (studi kasus desa Cocong Tengah Kecamatan Concong Kabupaten Indragiri Ilir Provinsi Riau) yang menggunakan sistem Rain Water Harvesting sederhana yaitu atap sebagai catchment area, pipa sebagai sistem pengaliran, dan tangki sebagai system penyimpanan. Hasil utama penelitian dengan melakukan simulasi model di wilayah penelitian untuk berbagai variasi data curah hujan menggunakan sampel luas atap $70 \mathrm{~m}^{2}$ serta jumlah penghuni rumah sebanyak 5 orang. Hasil simulasi membuktikan bahwa curah hujan merupakan parameter yangsangat sensitip terhadap pemenuhan hidrologi kuantitatif guna pemenuhan kebutuhan air bersih di pulau kecil..

Pemanfaatan air hujan diberbagai belahan dunia juga telah dimanfaatkan untuk kebutuhan pemenuhan air bersih seperti merujuk hasil penelitian oleh Nurdin et al (2019). Hasil penelitian dari pemanenan dan pengolahan air hujan menjadi air minum, didapatkan volume potensi hujan yang terjadi pada lokasi penelitian adalah $284,75 \mathrm{~mm} /$ bulan dengan kualitas air hujan setelah pengolahan dengan melalui proses penyaringan dan penambahan sodium bicarbonate $1 \mathrm{gr} / 10$ liter menghasilkan kualitas air hujan yang memenuhi syarat sebagai air minum.

Pada sisi lain, permasalahan kesulitan air menjadi hal utama serta banyaknya bekasbekas ceruk sisa penambangan batu kapur merupakan dua permasalahan yang berbeda. Sedangkan karakteristik batuan karst di daerah bukit Pecatu dapat meloloskan, melarutkan, dan meresap air hujan. Namun dalam penelitian ini, mencoba menggabungkan permasalahan tersebut menjadi sebuah solusi dengan tujuan membuat eksperimen yang mampu membuat batu kapur dari Bukit Pecatu memiliki potensi menahan air dalam jangka waktu yang lama dalam bentuk model waduk miniatur. Model waduk miniatur ini dibuat dengan campuran suspensi tanah liat yang berbagai konsentrasi $(0 \%, 5 \%, 10 \%$ dan 15\%). Model waduk miniature ini diuji debit dan daya serap air hujan untuk mengetahui kemampuan dalam menambung air hujan.

\section{Materials and Methods}

Tahapan pada penelitian ini dimulai dari proses pembuatan waduk mini, yaitu pembuatan waduk mini dari batu kapur Bukit Pecatu tanpa campuran tanah liat (kontrol) dan pembuatan waduk mini yang ditambahkan suspensi tanah liat berbagai konsentrasi. Sedangkan pelaksanaan meliputi uji eksperimen dengan penambahan air hujan, selanjutnya dianalisis debit air dan daya serap air hujan pada waduk mini yang di berikan perlakuan. Adapun tahapan penelitian yang di lakukan sebagai berikut. 


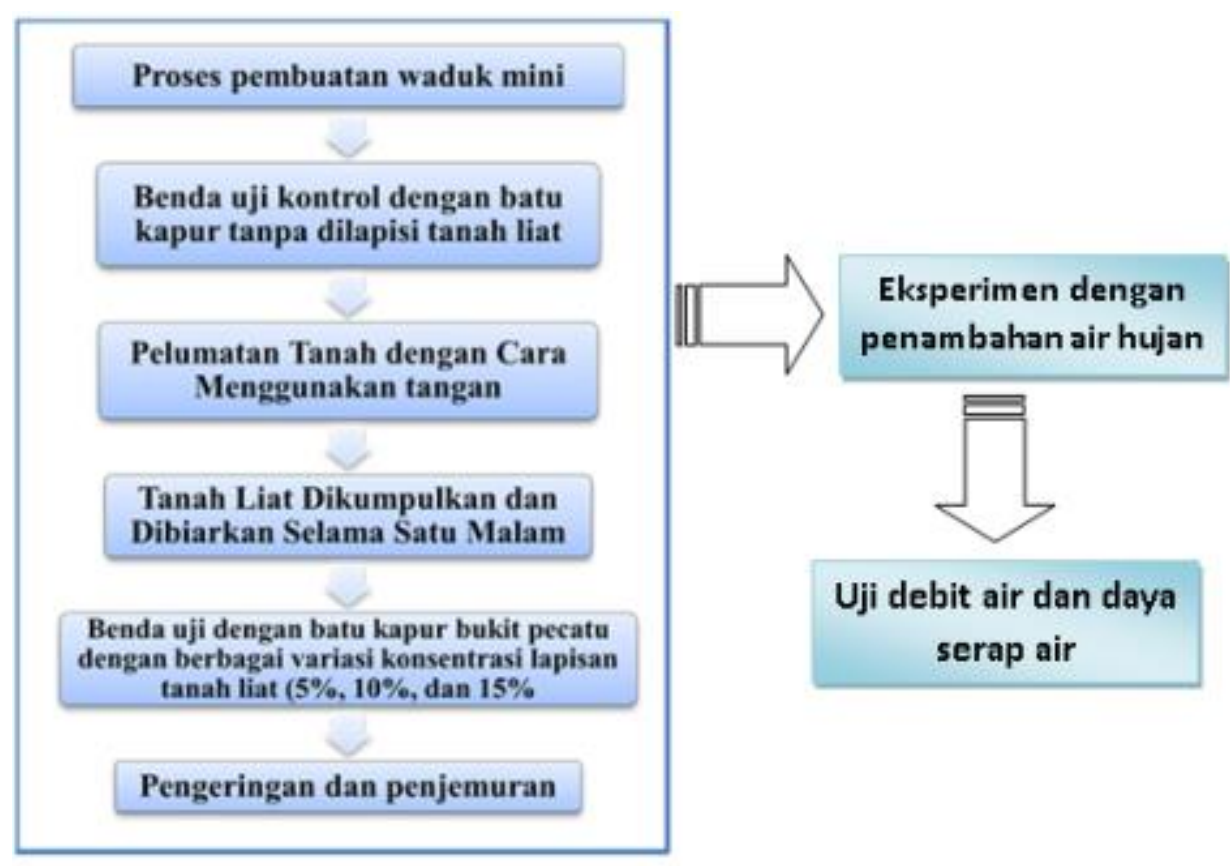

Gambar 3. Bagan Tahapan Penelitian

Penelitian ini termasuk dalam jenis penelitian eksperimen, yang tujuannya untuk menganalisis campuran tanah liat dengan variansi konsentrasi $0 \%, 5 \%, 10 \%$ dan $15 \%$ pada batu kapur Bukit Pecatu dalam pembuatan waduk miniatur sebagai instrumen pemanen dan penampung air hujan. Jenis Data dalam penelitian ini adalah data primer yaitu data yang diambil langsung terhadap objek penelitian dengan cara membuat dan melakukan pengujian terhadap benda uji. Pengambilan data dilakukan dengan cara mencatat semua data yang didapat pada waktu proses pembuatan benda uji maupun pada saat pelaksanaan pengujian.

Pengujian pada penelitian ini dilakukan dengan cara memberikan perlakuan pada batu kapur yang diambil secara sampling di wilayah Bukit Pecatu untuk menguji daya tahan terhadap air hujan. Uji yang dilakukan meliputi uji debit air dan daya serap air hujan.

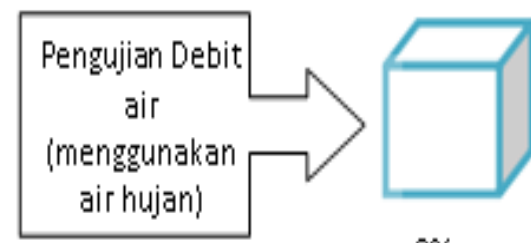

$0 \%$

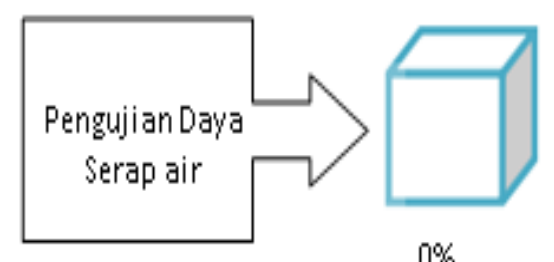

$0 \%$

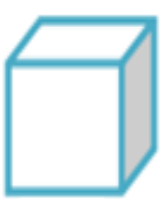

$5 \%$

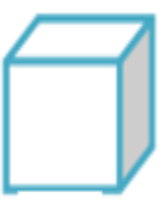

$5 \%$

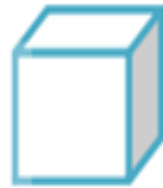

$10 \%$

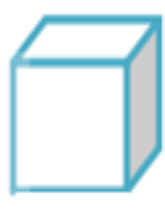

$10 \%$

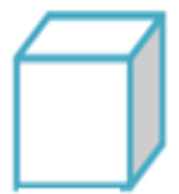

$15 \%$

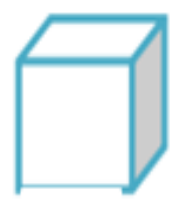

$15 \%$

Gambar 4. Komposisi Sampel untuk Pengujian Daya Tahan Terhadap Air Hujan 
Sampel yang dibuat terdiri dari 8 sampel. Setiap komposisi terdiri dari dua sampel yaitu 4 sampel untuk pengujian debit air dan 4 sampel untuk pengukuran daya serap air. Pengujian debit air akan dibagi berdasarkan pemberian debit 1,5 liter pada masing-masing waduk miniatur, kemudian ketahanan akan dihitung berdasarkan waktu hambat. Sesi 1 akan diberkan waktu 12 jam. Setelah itu 24 jam pada sesi berikutnya. Setiap sesi akan diulang dengan melakukan pengukuran. Adapun hasil penelitian akan disajikan dalam bentuk grafik / tabel pada masing-masing model untuk melihat penyusutan debit air yang ditambahkan persatuan waktu (Suryana \& Wijayanti, 2020). Sedangkan untuk uji daya serap air dilakukan dengan cara merendam pada suatu wadah yaitu baskom berisi air selama 24 jam. Pengujian daya serap adalah persentase dari perbandingan antara selisih massa basah dan massa kering dengan massa kering. Pengujian daya serap air dapat dihitung dengan persamaan berikut (Sembiring \& Saruksuk, 2018).

$$
\text { Daya Serap Air }=\frac{M 1-M 2}{M 2} 100 \%
$$

Keterangan:

M1 : Massa basah benda uji (gram)

M2 : Massa kering benda uji (gram)

\section{Results and Discussion}

Uji debit air pada waduk miniatur batu kapur Bukit Pecatu dilakukan dengan cara menambahkan air hujan dengan volume/debit yang sama pada masing-masing miniatur berbahan dasar batu kapur tersebut, yang sudah dicampur dengan suspensi tanah liat $(0 \%$, $5 \%, 10 \%$, dan 10\%). Adapun hasil analisis uji debit air pada waduk miniatur batu kapur Bukit Pecatu disajikan pada Tabel 1.

Tabel 1. Analsis Uji Debit Air Waduk Miniatur Batu Kapur Bukit Pecatu

\begin{tabular}{|c|c|c|c|c|c|}
\hline Uji & $\begin{array}{c}\text { Konsentrasi } \\
\text { Tanah Liat }\end{array}$ & $\begin{array}{c}\text { Tahapan } \\
\text { ke- }\end{array}$ & Debit air & $\begin{array}{c}\text { Laju } \\
\text { Penyusutan }\end{array}$ & Ket \\
\hline \multirow{4}{*}{ A } & \multirow{3}{*}{$0 \%$} & 1 & $0,5 \mathrm{~L}$ & $0,1 \mathrm{~L} / \mathrm{menit}$ & \multirow{3}{*}{ kontrol } \\
\hline & & 2 & $0,5 \mathrm{~L}$ & $0,1 \mathrm{~L} /$ menit & \\
\hline & & 3 & $0,5 \mathrm{~L}$ & $0,1 \mathrm{~L} / \mathrm{menit}$ & \\
\hline & \multirow{3}{*}{$5 \%$} & 1 & $0,5 \mathrm{~L}$ & $0,5 \mathrm{~L} / \mathrm{menit}$ & \multirow{3}{*}{-} \\
\hline \multirow[t]{3}{*}{ B } & & 2 & $0,5 \mathrm{~L}$ & $0,5 \mathrm{~L} / \mathrm{menit}$ & \\
\hline & & 3 & $0,5 \mathrm{~L}$ & $0,5 \mathrm{~L} / \mathrm{menit}$ & \\
\hline & \multirow{3}{*}{$10 \%$} & 1 & $0,5 \mathrm{~L}$ & $0,05 \mathrm{~L} / \mathrm{menit}$ & \multirow{3}{*}{-} \\
\hline \multirow[t]{3}{*}{$\mathrm{C}$} & & 2 & $0,5 \mathrm{~L}$ & $0,05 \mathrm{~L} / \mathrm{menit}$ & \\
\hline & & 3 & $0,5 \mathrm{~L}$ & $0,05 \mathrm{~L} / \mathrm{menit}$ & \\
\hline & \multirow{3}{*}{$15 \%$} & 1 & $0,5 \mathrm{~L}$ & $0,04 \mathrm{~L} / \mathrm{menit}$ & \multirow{3}{*}{-} \\
\hline \multirow[t]{2}{*}{$\mathrm{D}$} & & 2 & $0,5 \mathrm{~L}$ & 0,04 L/menit & \\
\hline & & 3 & $0,5 \mathrm{~L}$ & $0,04 \mathrm{~L} / \mathrm{menit}$ & \\
\hline
\end{tabular}




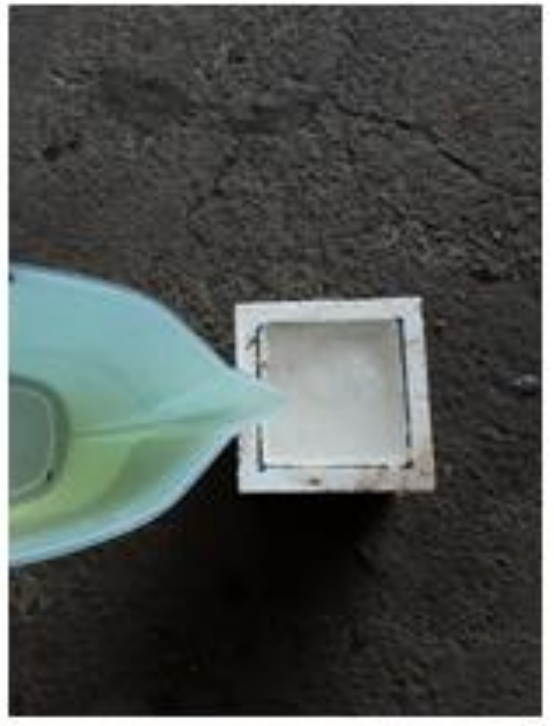

(a)

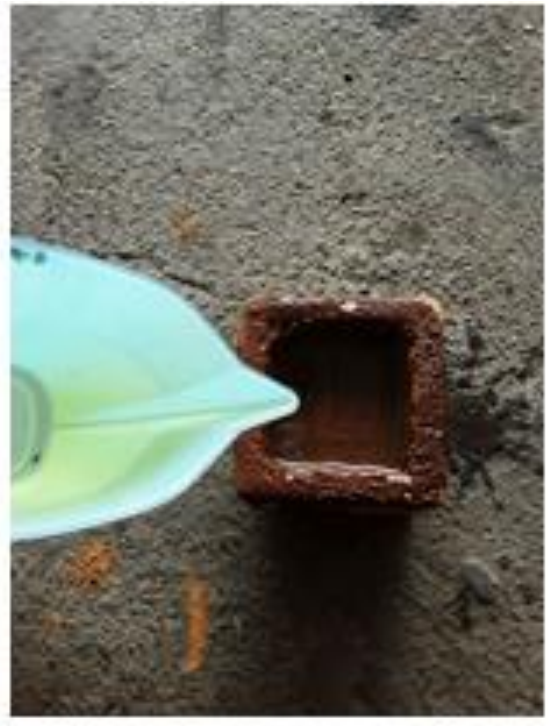

(b)

Gambar 5. Pengujian Debit Air dengan Air Hujan, (a) Tanpa Suspensi Tanah Liat; (b) Dicampur dengan Suspensi Tanah Liat

Pengujian daya serap air hujan dilakukan untuk mengetahui kemampuan waduk miniatur batu kapur Bukit Pecatu yang sudah diberikan campuran suspensi tanah liat, dalam menyerap air hujan. Pengujian dilakukan dengan cara merendam pada suatu wadah yaitu baskom berisi air selama 24 jam. Penentuan daya serap air pada waduk tersebut dapat diperoleh dari hasil pengukuran massa kering dan massa basah yang masing-masing diukur menggunakan alat timbangan analog. Berikut hasil perhitungan daya serap air hujan pada waduk miniatur yang menggunakan batu kapur Bukit Pecatu yang dicampur dengan suspensi tanah liat disajikan pada Tabel 2.

Tabel 2. Analsis Uji Daya Serap Air Hujan Waduk Miniatur Batu Kapur Bukit Pecatu

\begin{tabular}{ccccc}
\hline \multirow{2}{*}{ Benda Uji } & $\begin{array}{c}\text { Lapisan Tanah } \\
\text { Liat }\end{array}$ & \multicolumn{2}{c}{ Berat Waduk Miniatur } & \multirow{2}{*}{$\begin{array}{c}\text { Penyerapan } \\
\text { Air (\%) }\end{array}$} \\
\cline { 3 - 4 } & $0 \%$ & 1543,80 & 1250,70 & 23,43 \\
A & $5 \%$ & 1505,50 & 1300,30 & 15,78 \\
B & $10 \%$ & 1504,90 & 1319,10 & 14,09 \\
C & $15 \%$ & 1507,10 & 1358,90 & 10,91 \\
D & & & \\
\hline
\end{tabular}




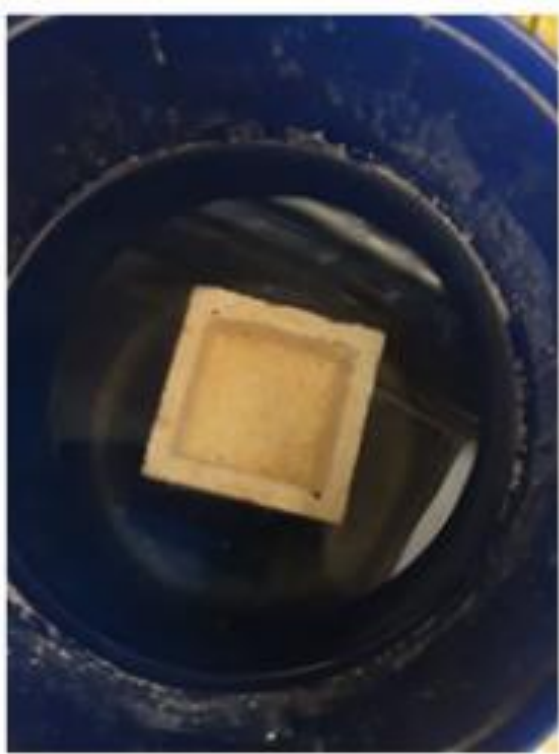

(a)

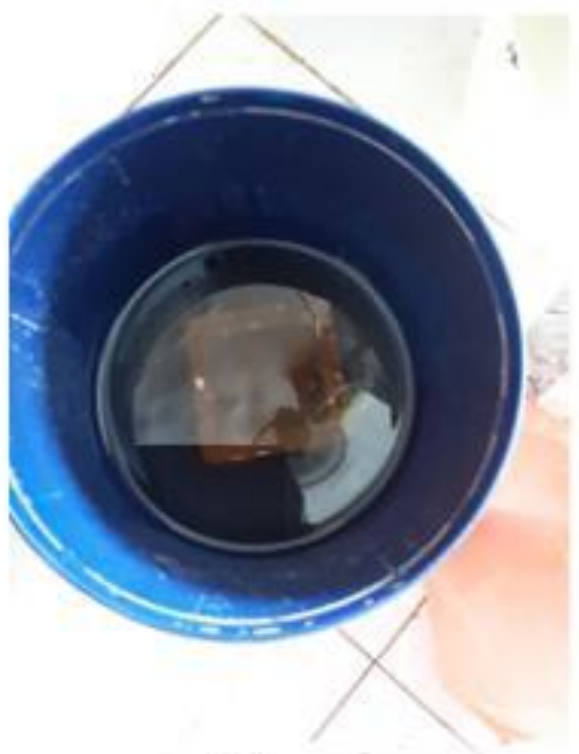

(b)

Gambar 6. Pengujian Daya Serap Air dengan Air Hujan, (a) Tanpa Suspensi Tanah Liat; (b) Dicampur dengan Suspensi Tanah Liat

Berdasarkan hasil uji debit air terlihat waduk miniatur batu kapur Bukit Pecatu dengan suspensi tanah liat konsentrasi $15 \%$ dapat menghambat laju air hujan lebik baik, yaitu sebesar 0,04L/menit (Tabel 1) dibandingkan dengan yang lainnya. Sedangkan untuk melihat daya tampung dari waduk ini dilakukan uji daya serap air (Gambar 6). Dari pengujian daya serap air diperoleh, waduk miniatur batu kapur Bukit Pecatu yang dengan suspensi tanah liat konsentrasi $15 \%$ memberikan daya serap yang lebih kecil yaitu sebesar 10,91\% (Tabel 2) dibandingkan dengan konsentrasi yang lainnya. Penelitian ini juga di dukung oleh penelitian yang dilakukan MS (2018), pencampuran batu kapur dan tanah liat pada pembuatan batu bata tanpa di bakar memberikan daya serap yang kecil dan memiliki daya tekan yang baik Andayono et al. (2019), melaporkan karakteristik batu bata campuran hasil sedimentasi penambangan batu gamping area 412,3 ha Bukit Tajarang memberikan hasil daya serap air yang kecil yaitu sebesar 14,16\%. Limestone dan chalk adalah batuan yang unik karena secara fisik menunjukkan masa batuan yang sangat kuat namun sangat rentan dan mudah terkikis oleh air dan pelapukan (Ardana \& Aribudiman, 2019). Penambahan tanah liat dapat membantu penutupan pori-pori batu kapur pada saat proses pelapukan secara kimiawi, sehingga dapat menghambat resap air (Yuskar et al., 2017).

Proses pelapukan batu kapur dibagi menjadi tiga jenis, yaitu pelapukan fisis, organik, dan kimiawi. Pelapukan fisis adalah pelapukan yang disebabkan oleh perubahan suhu dan air. Pelapukan jenis ini akan mengakibatkan batuan rusak secara fisik, dari batuan yang besar menjadi kecil dan dari batuan kecil menjadi halus. Proses pelapukan fisis hanya merubah ukuran dan bentuk batuan tanpa mengubah susunan kimia batuan tersebut. Pelapukan fisis disebut juga pelapukan mekanis karena prosesnya yang berlangsung secara mekanik. Pelapukan fisis dapat terjadi karena hal-hal berikut. Pertama, adanya perbedaan temperatur (suhu) yang besar. Peristiwa ini sering terjadi di daerah beriklim kontinental (iklim benua) atau beriklim gurun. Di daerah gurun, temperatur pada siang hari dapat mencapai hingga 45 ${ }^{0} \mathrm{C}$. Kondisi ini menyebabkan batuan mengembang. Sedangkan pada malam hari suhu dapat mencapai $-4{ }^{0} \mathrm{C}$ yang menyebabkan batuan mengalami pengerutan. Hal ini terjadi secara terus menerus, sehingga batu menjadi retak-retak atau pecah. Kedua, pembekuan air di dalam poripori batuan. Saat air membeku, air akan mengalami pemuaian pada volumenya dan 
menimbulkan tekanan pada lapisan batuan. Karena tekanan tersebut, batuan menjadi retak. Di daerah beriklim sedang, pembekuan terjadi dengan hebat karena temperatur udaranya yang sangat rendah. Ketiga, mengkristalnya air garam. Jika suatu air mengandung garam dan mengalami penguapan, maka garam akan tertinggal dalam bentuk kristal. Kristal-kristal garam ini berbentuk tajam dan dapat merusak lapisan batuan disekitarnya.

Sementara pelapukan organik adalah pelapukan yang disebabkan oleh aktivitas organisme seperti jamur, bakteri, hewan, tumbuhan atau manusia. Adapun hewan yang dapat menyebabkan pelapukan antara lain cacing tanah, serangga, dan tikus. Pelapukan yang disebabkan oleh tumbuhan dapat bersifat mekanis dan kimiawi. Pelapukan mekanis tumbuhan berupa penjalaran akar tumbuhan di dalam tanah yang dapat merusak batuan disekitarnya. Pelapukan kimiawi tumbuhan berupa perusakan batuan oleh asam-asam yang dikeluarkan oleh akar saat mengisap garam mineral (Endarto et al., 2016). Sedangkan pelapukan kimiawi atau dikenal dengan Karstifikasi adalah proses pelarutan, proses korosi batuan secara kimia oleh air pada batuan gamping, gipsum, batu garam atau batuan lain yang mudah larut yang bertanggung jawab terhadap terbentuknya fenomena karst baik di permukaan maupun bawah permukaan bumi (Rachmi, 2018). Pada pelapukan kimiawi, batuan tidak hanya mengalami perubahan bentuk dan ukuran, tetapi juga mengalami perubahan susunan kimia batuan tersebut. Pelapukan kimiawi umumnya berupa pelarutan. Pelapukan kimiawi dapat dengan jelas kita saksikan di daerah pegunungan kapur (karst) (Yudha \& Haryono, 2017).

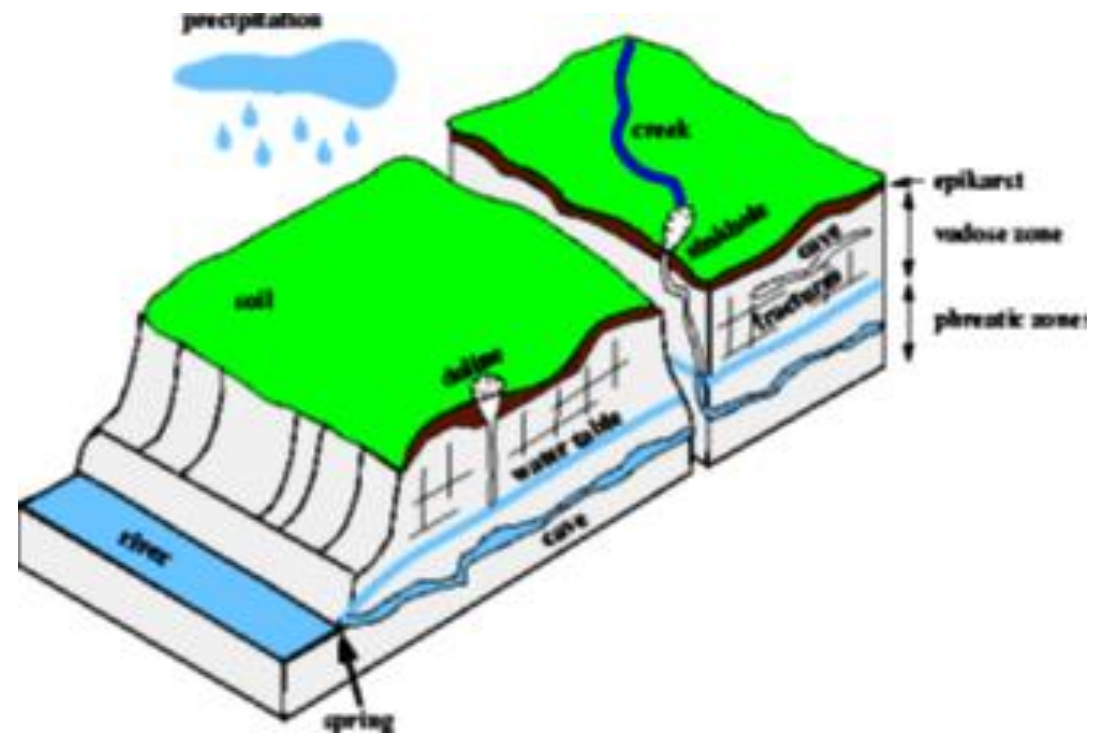

Gambar 7. Awal Terbentuknya Karst

(Yudha \& Haryono, 2017)

Karstifikasi atau proses permbentukan bentuk lahan karst didominasi oleh proses pelarutan. Pelapukan di daerah ini terjadi akibat pengaruh air hujan dan didorong oleh temperatur yang tinggi. Air hujan yang banyak mengadung $\mathrm{CO}_{2}$ (zat asam arang/karbon dioksida) akan dengan mudah melarutkan bata kapur $\left(\mathrm{CaCO}_{3}\right)$. Reaksi karbon dioksida $\left(\mathrm{CO}_{2}\right)$ di udara dengan air hujan $\left(\mathrm{H}_{2} \mathrm{O}\right)$ menghasilkan $\mathrm{H}_{2} \mathrm{CO}_{3}$ yang bersifat asam lemah (Yudha \& Haryono, 2017). Larutan $\mathrm{H}_{2} \mathrm{CO}_{3}$ tidak stabil terurai menjadi $\mathrm{H}^{+}$dan $\mathrm{HCO}_{3}{ }^{2-}$. Ion $\mathrm{H}^{+}$inilah yang selanjutnya menguraikan $\mathrm{CaCO}_{3}$ menjadi $\mathrm{Ca}^{2+}$ dan $\mathrm{HCO}_{3}{ }^{2-}$. Dengan mengalirnya larutan tersebut melalui aliran air permukaan (run off) yang dapat melarutkan batu gamping mengakibatkan terbentuk celah. Penambahan tanah liat dapat membantu penutupan celah 
yang terbentuk dan pori-pori batu kapur, sehingga mampu menghambat resapan air hujan. Secara ringkas proses pelarutan dirumuskan dengan reaksi sebagai berikut.

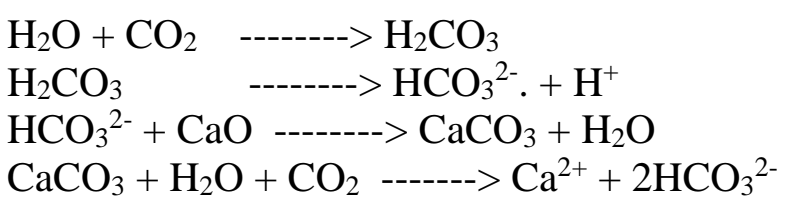

Proses pelarutan batu kapur sebagaimana dalam gambar di bawah ini.

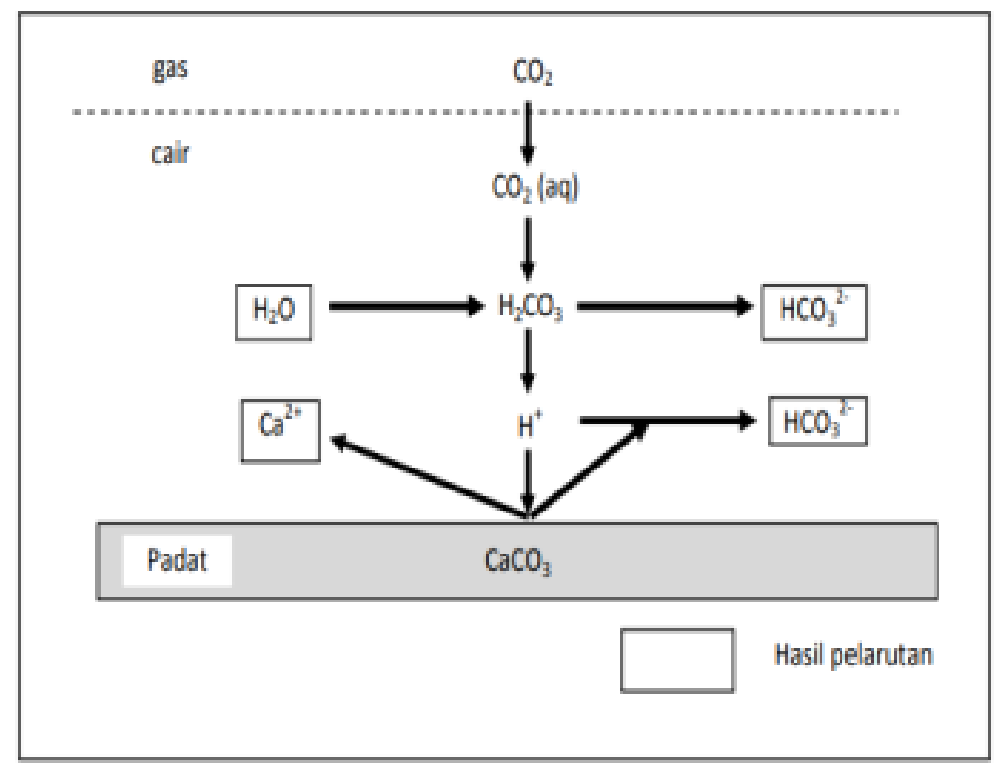

Gambar 8. Proses Pelarutan Batu Kapur Secara Kimia

(Nofirman, 2017)

Penambahan suspensi tanah liat pada pembuatan waduk miniatur batu kapur Bukit Pecatu ini berfungsi sebagai penutup celah yang terbentuk pada saat proses pelapukan. Mineral lempung/tanah liat merupakan koloid dengan ukuran sangat kecil (kurang dari 1 mikron) (Joseph et al., 2016). Masing-masing koloid terlihat seperti lempengan-lempengan kecil yang terdiri dari lembaran-lembaran kristal yang memiliki struktur atom yang berulang (Jumingin \& Setiawati, 2016). Campuran tanah liat/lempung yang memiliki struktur sangat halus dan kecil ini mampu secara perlahan menutupi pori-pori batu kapur, sehingga dapat menghambat laju resapan air hujan. Hal ini terbukti dari hasil pengujian debit dan daya serap air hujan dengan menggunakan suspensi tanah liat yang berkonsentrasi $15 \%$ pada waduk miniatur batu kapur Bukit Pecatu dapat menghambat laju resapan air hujan dan memiliki daya serap yang kecil. Dengan ini menunjukkan campuran suspensi tanah liat $15 \%$ pada pembuatan waduk miniatur batu kapur Bukit Pecatu memiliki daya tahan air hujan yang baik. Sehingga berpotensi sebagai instrumen pemanen dan penampung air hujan.

Implementasi dalam penelitian ini menerapkan pembuatan waduk miniatur dari batu kapur Bukit Pecatu, Jimbaran, Badung yang dicampur dengan suspensi tanah liat. Variasi Konsentrasi suspensi tanah liat yang di gunakan adalah $0 \%, 5 \%, 10 \%$ dan $15 \%$. Waduk Miniatur yang sudah dibuat, selanjutnya dilakukan pengujian debit air dan daya serap air. Hal ini dilakukan untuk melihat potensi dari batu kapur Bukit Pecatu sebagai instrumen pemanen dan penambung air hujan. Sebagai pemanen air hujan waduk yang disiapkan harus dapat memperkirakan debit air hujan yang masuk. Pengujian debit air hujan dilakukan dengan 
menggunakan air hujan secara bertahap 0,5 L pertama dan kedua diberbagai variasi konsentrasi campuran suspensi tanah liat (Gambar 5).

\section{Conclusion}

Berdasarkan hasil pengujian debit dan daya serap air hujan yang menggunakan campuran suspensi tanah liat konsentrasi $15 \%$ mampu menghambat laju resapan air pada batu kapur bukit Pecatu. Secara teoritis bukit kapur Pecatu dapat diteliti untuk rancangan tendon raksasa melalui jalur alami air pada Karst. Dengan demikian maka kebutuhan masyarakat Pecatu dan sekitarnya akan air bersih baik untuk pertanian dan konsumsi dapat terpenuhi. Penelitian selanjutnya diharapkan dapat melakukan pengujian struktur kimia kompleks pada batu kapur Bukit Pecatu, penelitian terkait dengan pemetaan sebaran karst di daerah desa bukit Pecatu, dan pengujian langsung di lokasi agar hasil lebih akurat serta melakukan pengolahan air hujan menjadi menjadi air minum.

\section{References}

Ali, I., Suhardjono, S., \& Hendrawan, A. P. (2017). Pemanfaatan Sistem Pemanenan Air Hujan (Rainwater Harvesting System) Di Perumahan Bone Biru Indah Permai Kota Watampone Dalam Rangka Penerapan Sistem Drainase Berkelanjutan. Jurnal Tenik Pengairan, 8(1), 26-38. https://doi.org/10.21776/ub.jtp.2017.008.01.03

Andayono, T., Juliafad, E., \& Halim, R. (2019). Karakteristik Batu Bata Campuran Hasil Sedimentasi Penambangan Batu Gamping Area 412,3 Ha Bukit Tajarang. INVOTEK: Jurnal Inovasi Vokasional Dan Teknologi, 19(1), 105-112. https://doi.org/10.24036/invotek.v19i1.581

Ardana, M. D. W., \& Aribudiman, I. N. (2019). Analisis Karakteristik Batuan Kapur (Limestone Dan Chalk) Di Kawasan Bukit Pecatu Kabupaten Badung Bali. Jurnal Ilmiah Teknik Sipil, 23(1), 1-5.

Endarto, R., Gunawan, T., \& Haryono, E. (2016). Kajian Kerusakan Lingkungan Karst Sebagai Dasar Pelestarian Sumberdaya Air (Kasus Di Das Bribin Hulu Kabupaten Gunungkidul Daerah Istimewa Yogyakarta). Majalah Geografi Indonesia, 29(1), 51. https://doi.org/10.22146/mgi.13099

Garinas, W. (2020). Karakteristik Batu Kapur Dalam Negeri Untuk Bahan Baku Pendukung Pengolahan Bijih Besi/Baja. Prosiding Temu Profesi Tahunan PERHAPI, 1(1), 3338. https://doi.org/10.36986/ptptp.v1i1.47

Joseph, S., Bishnoi, S., \& Maity, S. (2016). An economic analysis of the production of limestone calcined clay cement in India. Indian Concrete Journal, 90(11), 22-27.

Jumingin, \& Setiawati, S. (2016). Kajian Ketebalan Tanah Liat Sebagai Bahan Dielektrik Kapasitor Plat Sejajar. Sainmatika: Jurnal Ilmiah Matematika Dan Ilmu Pengetahuan Alam, 13(1), 22-26. https://jurnal.univpgripalembang.ac.id/index.php/sainmatika/article/view/960

Mays, A. Z., Rai, N. I. N., Ng, S. I., \& Zea, C. (2015). Simulasi Pemanenan Air Hujan Irigasi pada Budidaya Tanaman Jagung (Zea Mays). Jurnal Teknik Pertanian Lampung, 4(1), 9-18.

Megawati Alimuddin; Abdul Kadir, Laode, M. A. (2019). Komposisi Kimia Batu Kapur Alam Dari Indutri Kapur Kabupaten Kolaka Sulawesi Tenggara. Saintifik, 5(Vol 5 No 2 (2019): Saintifik: Jurnal Matematika, Sains, dan Pembelajarannya), 104-108. https://doi.org/10.31605/saintifik.v5i2.230

MS, H. S. (2018). Pengaruh Campuran Kapur dengan Tanah Liat sebagai Bahan untuk Pembuatan Batu Bata Tanpa Dibakar. Jurnal Momentum, 20(1), 4-7. https://doi.org/10.21063/JM.2018.V20.1.52-59 
Nofirman. (2017). Sebaran Bukit Karst di Wilayah Kabupaten Sijungjung. Jurnal Geografflesia, 2(1), 73-83.

Nurdin, A., Lembang, D., \& Kasmawati, K. (2019). Model Pemanenan Dan Pengolahan Air Hujan Menjadi Air Minum. Teknik Hidro, 12(2), 11-19. https://doi.org/10.26618/th.v12i2.2806

Rachmi, I. N. (2018). Kajian dan Studi Literatur berbagai mata air dan sungai bawah tanah Daerah. Departemen Geografi Lingkungan Fakultas Geografi Universitas Gadjah Mada, 1-8.

Rahim, S. E., \& Damiri, N. (2018). Pemanenan Air Hujan Dan Prediksi Aliran Alternatif Penyediaan Air Bersih. Prosiding Seminar Nasional Hari Air Dunia, 131-140.

Riyanto, E., \& Agung Setiawan. (2020). Pemanenan Air Hujan Menggunakan Ground Water Tank untuk Pemenuhan Air Baku Di lokasi Bangunan Perkuliahan (Lokasi Penelitian: Kampus 3, UM Purworejo). Semesta Teknika, 23(1), 54-62. https://doi.org/10.18196/st.231255

Rochmah, N. (2016). Pemanfaatan Batu Kapur Didaerah Sampang Madua sebagai Bahan Pengganti Agregat Kasar pada Campuran Beton. JHP17 Jurnal Hasil Penelitian LPPM Untag Surabaya, 01(02), 217-226.

Rohmaningsih, E., Sholichin, M., \& Haribowo, R. (2017). Kajian Pengembangan Sistem Penyediaan Air Bersih Pada Daerah Rawan Air Di Desa Sumbersih Kecamatan Panggungrejo Kabupaten Blitar. Jurnal Tenik Pengairan, 8(1), 48-59. https://doi.org/10.21776/ub.jtp.2017.008.01.05

Sembiring, A. C., \& Saruksuk, J. J. (2018). Uji Kuat Tekan Dan Serapan Air Pada Paving Block dengan Bahan Pasir Kasar, Batu Kacang, dan Pasir Halus. JURITI PRIMA (Junal Ilmiah Teknik Industri Prima), I(1). https://doi.org/https://doi.org/10.5281/zenodo.1207331

Suprayogi, Bochari, Suwondo, \& Asmura, J. (2017). Pemanfaatan Pemanenan Air Hujan Skala Individu Untuk Kebutuhan Air Bersih Pada Pulau Kecil (Studi Kasus Desa Cocong Tengah Kecamatan Concong Kabupaten Indragiri ilir Provinsi Riau). Jurusan Teknik Sipil ,Fakultas Teknik, Universitas Riau, 17(1), 9-15.

Suryana, I. G. P. E., \& Wijayanti, N. W. E. (2020). Potensi Batu Kapur Bukit Pecatu Sebagai Instrumen Pemanen Dan Penampung Air Hujan. Media Komunikasi Geografi, 21(1), 74-83. https://doi.org/10.23887/mkg.v21i1.23089

VA, D. P. R., ARTINI, N. P. R., \& ARYASA, I. W. T. (2017). Penelitian pendahuluan kualitas air tanah. Jurnal Ilmiah Medicamento, 3(1), 39-43.

Widiarso, D. A., Kusuma, I. A., \& Fadhlillah, A. P. (2018). Penentuan Potensi Sumberdaya Batu Gamping Sebagai Bahan Baku Semen Daerah Gandu Dan Sekitarnya, Kecamatan Bogorejo, Kabupaten Blora, Jawa Tengah. Teknik, 38(2), 92. https://doi.org/10.14710/teknik.v38i2.13213

Y.Ulfa, Putra, A. A. B., \& Simpen, I. N. (2015). Karakterisasi Batu Kapur Alam Bukit Jimbaran Bali. Jurnal Kimia (Journal of Chemistry), 13(1), 67-73. https://doi.org/https://doi.org/10.24843/JCHEM.2019.v13.i01.p11

Yudha, M. P., \& Haryono, E. (2017). Kajian Variabilitas CaCO3 Terlarut Untuk Mengetahui Tingkat Pelarutan dan Penyerapan Karbon Atmosfer Dalam Proses Karstifikasi Kawasan Karst Rembang. Jurnal Bumi Indonesia, 6(4).

Yuskar, Y., Choanji, T., \& Buburanda, H. (2017). Karstifikasi dan Pola Struktur Kuarter Berdasarkan Pemetaan Lapangan dan Citra SRTM Pada Formasi Wapulaka, Pasar Wajo, Buton, Sulawesi Tenggara. Journal of Earth Energy Engineering, 6(1), 1-10. https://doi.org/10.22549/jeee.v6i1.66 